\title{
Pelayanan Pastoral Dengan Aspek-Aspeknya di Gereja Bethel Indonesia Jemaat Sungai Yordan Surabaya
}

\author{
Fatony Pranoto' ${ }^{1}$, Ivonne Eliawaty ${ }^{2)}$, Surja Permana ${ }^{3)}$, \\ Evangelical Theological Seminary of Indonesia - Surabaya \\ E-mail:fatonypranoto@sttii-surabaya.ac.id \\ 2) Evangelical Theological Seminary of Indonesia - Surabaya \\ E-mail: ivonne_fatony@yahoo.com \\ 3) Evangelical Theological Seminary of Indonesia - Surabaya \\ E-mail: surjapermana@sttii-surabaya.ac.id
}

\begin{abstract}
Pastoral service is a spiritual service and should not be ignored in the pastoral ministry. At GBI the Jordan River Surabaya has provided several models of material services: Money / goods to help congregations in need; Spiritually: introducing people to Jesus Christ and to life in the Holy Spirit or led by the Spirit, new born life becomes a new creation (not only identity / without repentance; Healing: making others healthy, both physical, mental and emotional as well as; Prophetic: changing the way of human life in the structure of society. Improve people's way of life (especially in rural areas).
\end{abstract}

Keywords: Pastoral Service, Congregations, Spiritual

\section{PENDAHULUAN}

Pelayanan pastoral merupakan pelayanan yang bersifat rohani dan tidak boleh diabaikan di dalam pelayanan penggembalaan. Ketika Tuhan Yesus melayani di bumi ini, Ia telah memberikan contoh pelayanan nyata seperti yang tertulis di dalam ke empat Injil. Sebagai contohnya adalah di dalam Matius 9:35-38. Ayat-ayat tersebut mengajarkan beberapa hal penting, seperti :

Pertama adalah sikap Tuhan Yesus terhadap pelayanan (35). Tuhan Yesus melayani berkeliling ke semua kota dan desa. Berkeliling merupakan sikap pro-aktif dan merupakan inisiatif dari diri sendiri. Pelayanan itu tidak harus menunggu jadwal / diperintah! Jadwal pelayanan hanya untuk menjaga keteraturan dan keharmonisan. Jika perlu menciptakan pelayanan sendiri. Ke semua kota dan desa menunjukkan bahwa Yesus tidak memilih ladang pelayanan. Semua tempat didatangi Yesus. Sebab fokus pelayanan Yesus adalah keselamatan jiwa-jiwa.

Sikap Yesus berikutnya adalah terhadap orang lain (35). Yesus juga mengajar dalam rumah-rumah ibadat. Mengajar berarti memberikan pengertian kebenaran Firman Allah dengan tujuan kedewasaan rohani. Ingat di akhir zaman ini telah banyak bermunculan ajaran-ajaran yang menyimpang dari Firman (Efesus 4:13-14).

Yesus juga memberitakan Injil yang berarti memperkenalkan Isi Injil, yaitu bahwa Tuhan Yesus adalah satu-satunya Juruselamat Dunia. Sebab ada sebagian orang yang telah memutarbalikkan Isi Injil, sehingga mereka memberitakan 'Yesus' yang lain, 'roh' yang lain dan 'Injil' yang lain (2 Korintus 11:4).

Pelayanan Yesus yang lain adalah melenyapkan penyakit dan kelemahan. Ini

merupakan pelayanan lahiriah. Di samping melayani perkara rohani, maka gereja juga harus memperhatikan kebutuhan lahiriah jemaat.

Hati Tuhan Yesus juga penuh dengan belas kasihan yang dinyatakan ketika manusia itu lelah, terlantar seperti domba tanpa gembala. Tandanya adalah mereka sedang mengalami kesulitan besar yang bertubi-tubi dan tidak tahu apa yang harus dikerjakannya serta tidak tahu meminta pertolongan kepada siapa. Itulah keadaan sekarang ini dalam gereja. Orang-orang seperti ini perlu mendapatkan pelayanan pastoral.

Dan terhadap tuaian (jiwa-jiwa) dalam ayat 37, Tuhan Yesus pernah berkata bahwa tuaian memang banyak, tetapi pekerja sedikit ! Para Gembala harus meminta pekerja-pekerja kepada Tuhan. Gembala Sidang harus sadar bahwa ada sikap mendesak di dalampelayanan 
pekerjaan Tuhan, khususnya dalam pelayanan pastoral. Kedua adalah dasar pelayanan Tuhan Yesus (36). Alkitab berkata bahwa

“...tergerakah hati Yesus oleh belas kasihan ..." Jadi kasih Kristuslah yang harus menguasai hamba-hamba Tuhan di dalam pelayanan (II Korintus 5:14-15). Sama seperti Allah Bapa mengutus Yesus karena mengasihi isi dunia ini (Yohanes 3:16), demikian juga orang percaya melayani dan hidup bagi Allah karena kasih. Bukan melayani karena "terpaksa" atau "jadwal" (untuk keteraturan saja). Contoh: Orang Farisi dan Ahli Taurat melayani Allah secara legalitas (diumpamakan seperti pohon ara yang banyak daunnya / berlimpah-limpah di dalam daun keagamaan, tetapi tidak berbuah / mandul dalam buah kebenaran - Markus 11:12-14).

Ketiga adalah motivasi pelayanan Tuhan Yesus (bd. Yohanes 4:34). Motivasi pelayanan Yesus adalah melakukan kehendak Bapa dan menyelesaikan pekerjaanNya. Ketaatan melakukan Firman Allah iu dibuktikan dalam hal:

hidup berdasarkan ketaatan Firman Allah (Yosua 1:8-9); di dalam pelayanan : seperti hambahamba yang mengasihi tuannya (Lukas 17:10) dan pengajarannya berdasarkan Alkitab. Ketaatan harus dilakukan meskipun beresiko menderita, seperti Yesus Kristus yang sudah menderita ketika masih berada di taman Getsemani (Markus 14:35-36, bd. Ibrani 12:4).Pada masa kini pelayanan yang memperhatikan jiwa-jiwa seperti itu sudah mulai pudar. Orang berlomba-lomba membangun gedung gereja yang megah dengan sarana dan prasarana yang mahal. Hal ini tidak salah! Tetapi ada yang lebih penting di balik semua itu, yaitu pembangunan manusia rohaniah. Fenomena demikianlah yang melatar-belakangi penulisan ini.

\section{Identifikasi Masalah}

Banyak orang beranggapan bahwa gereja yang bertumbuh ditandai dengan makin bertambahnya jumlah jemaat (secara kuantitas) dan sarana gedung gereja semakin besar, mewah dan megah. Pertanyaannya apakah dengan bertambahnya jumlah jemaat diikuti juga dengan makin bertumbuhnya kerohanian mereka (secara kualitas)? Atau dengan makin bertambahnya jumlah jemaat dan makin banyaknya aktivitas pembangunan gedung (sarana/prasarana) tidak diikuti dengan makin bertumbuhnya kerohanian jemaat yang ada, sebaliknya kerohanian jemaat semakin merosot?

\section{Ruang Lingkup Penulisan}

Penulisan ini menjelaskan tentang pelayanan pastoral dengan aspek-aspeknya di Gereja Bethel Indonesia Jemaat Sungai Yordan Surabaya yang berpengaruh bagi pertumbuhan jemaat, baik secara kualitas maupun kuantitas.

\section{Rumusan Masalah}

Untuk mempertajam pokok masalah di atas, maka Penulis akan mengemukakan beberapa rumusan masalah sebagai berikut : Pertama, Berapa banyak gereja yang masih memikirkan pertumbuhan rohani jemaatnya? Kedua, Bagaimana jemaat itu terus di bawa untuk semakin mengenal Kristus dengan benar (bd. Filipi 3:10)? Ketiga, Bagaimana pelayanan pastoral yang dikerjakan oleh gereja itu dapat berdampak positif (berpengaruh) dalam kehidupan jemaat?

\section{Tujuan Penulisan}

Adapun tujuan dari penulisan ini adalah Pertama, untuk mendapatkan wawasan dan pemahaman yang memadai mengenai dasardasar pelayanan pastoral secara teologis dan holistik dalam jemaat.Kedua, untuk dapat melakukan praktik pelayanan pastoral dengan pengertian yang benar. Ketiga, untuk dapat membawa jemaat supaya semakin bertumbuh dewasa mengenal Yesus Kristus dengan benar (Filipi 3:10), sehingga akhirnya dapat melayani Tuhan dan sesama.

Keempat, untuk menyelesaikan masalah yang timbul dalam kehidupan jemaat, supaya di tengah beban hidup yang berat sekalipun, tidak cepat menyalahkan Tuhan, tetapi sebaliknya tetap teguh dalam iman percayanya.

\section{Metode Penulisan}

Penulis menggunakan metode kepustakaan, yang dikenal dengan literatur untuk menyelesaikan karya tulis ini. Penulis juga mencari buku-buku penunjang yang bisa dijadikan bahan referensi dalam penyusunannya. Metode penulisan ini dikenal dengan metode kualitatif deskriptif.

\section{Pelayanan Pastoral}

Dalam Efesus 4:8-11 mengatakan bahwa Tuhan Yesus telah memberi "pemberianpemberian", yaitu jabatan di dalam gereja. Jabatan itu adalah Rasul, Nabi, Penginjil, Gembala dan Guru. Kata "memberi" dalam bahasa Yunani "edoke" mempunyai arti: Kristus memanggil orang-orang untuk melayani di dalam bermacam-macam fungsi. 
a. Rasul (Apostolos), artinya 'orang yang diutus / utusan'; memberitakan Injil di tempat yang baru. Mula-mula dipakai untuk 12 murid Yesus (Matius 10:2,16; Markus 6:30; Lukas 6:30; 9:10). Bukan Gelar / Pangkat, tetapi "nama / fungsi" yang diberikan berhubung dengan tugas yang harus dikerjakan: menjadi utusan Yesus dalam Pekabaran Injil. Pekerjaan Rasul meluas sampai ke seluruh dunia. Contoh : Petrus ke Kaisarea (Kisah Para Rasul 10), ke Korintus (I Korintus 1:12) dan akhirnya ke Roma (I Petrus 5:13). Yohanes lama bekerja di Asia Kecil (Wahyu 2-3), Paulus ke Yerusalem 3 tahun setelah pertobatannya, tidak dilihat seorang rasulpun, kecuali Yakobus, saudara Tuhan Yesus (Galatia 1:19). Ini berarti bahwa Rasul-rasul itu pergi ke seluruh dunia. Memegang "pimpinan" di jemaat : memberitakan Firman Allah dan mengajar (Kisah Para Rasul 2:3), menilik jemaat dan pekerjaan Pemberita Injil (Kisah Para Rasul 8:14) dan mengambil keputusan penting untuk seluruh gereja (Kisah Para Rasul 15). Pekerjaan Rasul berakibat penderitaan: Yakobus dibunuh oleh Agripa dan Petrus hampir mengalami nasib yang sama (Kisah Para Rasul 4-5:17; 12:2)

b. Nabi : dengan kemampuan / hikmat Allah memberitakan Injil. Tidak dipilih dan

diutus oleh Kristus dan merupakan suatu karunia dari Tuhan. Contoh: Nabi Agabus (Kisah Para Rasul 11:27). Kisah Para Rasul 13:1-3 mengatakan bahwa mereka mendapat wahyu ("kata Roh Kudus"). Roh Kudus memberitakan petunjuk yang berhubungan dengan situasi pada waktu itu dan yang akan datang.

Tuhan menetapkan Nabi dan Rasul untuk terwujudnya gereja (Kisah Para Rasul 2:19-20).

Dalam Perjanjian Lama, Tuhan mengutus para Nabi untuk membangun gereja.

Tetapi gereja juga belum terwujud. Dan di dalam Perjanjian Baru, Tuhan

mengutus para Rasul-Nya untuk mendirikan gereja. Pada masa Yesus masih hidup di dunia ini, gereja-Nyajuga belum terwujud. Tetapi setelah kematian, kebangkitan dan kenaikan Yesus Kristus ke Sorga, gereja lahir pada hari Pentakosta (Kisah Para Rasul 2:1-47). Karena gereja sudah berdiri, maka 'jabatan' Rasul dan Nabi otomatis tidak berlaku lagi (Efesus 2:19-20). Yang ada adalah "fungsi" Rasul dan Nabi, yaitu tetap konsisten memberitakan Firman Allah.

c. Penginjil : memberitakan Injil kepada kelompok-kelompok gereja (banyak orang),

KKR di lapangan-lapangan terbuka dll.

d. Gembala dan Guru : berada di satu ladang pelayanan di gereja lokal.

Contoh : Paulus dan Barnabas. Guru adalah suatu karunia. Ibrani 5:12 mengatakan

bahwa pelayanan 'guru' harus dikerjakan oleh seluruh jemaat.
Kisah Para Rasul 13:1-3 menegaskan bahwa tugas guru adalah menerangkan isi wahyu dengan bahasa yang biasa / terang dan bukan bahasa nubuat. Guru belum tentu Gembala, tetapi Gembala harus seperti Guru (ia harus cakap mengajar orang lain), seperti yang dinyatakan di dalam I Timotius 3:2.

Dalam pertumbuhan Gereja Bethel Indonesia jemaat Sungai Yordan Surabaya terdapat Pastor - Gembala (Yunani: Poimen $=$ menjaga, melindungi, membela). Gembala Sidang dijabat oleh Pendeta (Pdt.), dibantu oleh Pendeta Muda (Pdm.) dan Pendeta Pembantu (Pdp.). Seiring dengan bertambahnya waktu, jumlah jemaat terus mengalami pertumbuhan secara kuantitas, sehingga terbentuklah Tua-tua Penatua/Majelis seperti yang tertulis dalam Kisah Para Rasul 20:17 : orang tua (usia), sebab berhikmat dan berpengalaman.

Juga dibentuk Penilik Jemaat, seorang yang "benar" dan "setia" melakukan

kewajibannya. Kualifikasi pelayanan ini terdapat di dalam surat I Timotius 3:1-7 demikian : Benarlah perkataan ini: "Orang yang menghendaki jabatan penilik jemaat menginginkan pekerjaan yang indah". Karena itu penilik jemaat haruslah seorang yang tak bercacat, suami dari satu isteri, dapat menahan diri, bijaksana, sopan, suka memberi tumpangan, cakap mengajar orang, bukan peminum, bukan pemarah melainkan peramah, pendamai, bukan hamba uang, seorang kepala keluarga yang baik, disegani dan dihormati oleh anak-anaknya. Jikalau seorang tidak tahu mengepalai keluarganya sendiri, bagaimanakah ia dapat mengurus Jemaat Allah?

Janganlah ia seorang yang baru bertobat, agar jangan ia menjadi sombong dan kena hukuman Iblis. Hendaklah ia juga mempunyai nama baik di luar jemaat, agar jangan ia digugat orang dan jatuh ke dalam jerat Iblis.

Pertumbuhan kuantitas yang lain adalah dengan terbentuknya guru (Yunani: Didaskalos, Ibrani: Rabbi) untuk anak-anak Sekolah Minggu di GBI Sungai Yordan Surabaya. Sebab jumlah jemaat anak-anak juga bertambah banyak. Kualifikasinya terdapat di dalam I Timotius 1:3, yaitu orangorang tertentu (guru) supaya jangan mengajarkan ajaran lain. Surat II Timotius 2:2 menuliskan bahwa seorang guru harus juga cakap mengajar orang lain. 
Gereja Bethel Indonesia Sungai Yordan juga memberikan tugas pelayanan kepada jemaat awam. Mereka disebut sebagai Pelayan Tuhan yang di dalam bahasa Yunani terdapat tiga kata benda, yaitu : Diakonos, Leitourgos, Huperetes.

a. Diakonos - diakonia (Kisah Para Rasul 6:2). Arti hurufiahnya adalah pelayanan di meja makan / penyelenggaraan pemeliharaan hidup. Berasal dari kata "dia" yang berarti siap, selesai dan "konis" yang berarti debu. Jadi Diakonos berarti seorang yang dibangkitkan dari debu yang dengan tergesa-gesa siap melayani sampai selesai / tuntas. Mereka siap menjalankan perintah dari tuannya. Mereka adalah seorang yang aktif di dalam pekerjaannya. Dalam Matius 20:26-28 dikatakan bahwa siapa yang ingin "besar" harus menjadi 'pelayan' dan siapa yang ingin "terkemuka" harus menjadi 'hamba' terlebih dahulu. Contoh: Tuhan Yesus.

b. Leitourgos: palayanan yang dilakukan oleh bangsa-bangsa untuk kepentingan

politik. Mereka adalah pelayanan secara umum dan bersifat keagamaan yang dipimpin di mezbah. Hal ini berarti merupakan pelayanan yang menyeluruh (masyarakat). Surat Roma 13:4,6 mengatakan bahwa Pemerintah adalah hamba Allah. Pelayanan para imam yang melayani ibadah juga disebut sebagai 'leitourgos'(Ibr 8:2-6). Contoh : Paulus menjadi pelayan Kristus bagi bangsa-bangsa bukan Yahudi dalam pelayanan pemberitaan Injil (melayani bangsa Kafir). Jadi "leitourgos" adalah pemimpin keagamaan/penyembahan (=imam) dan Pemberita Injil.

c. Huperetes berarti pelayanan bersama, saling melengkapi, saling mengisi.

Contoh: Paulus dan Apolos dalam I Korintus 3:6. Kristus, Gembala Agung segala

domba (Ibrani 13:20) yang di bawahnya ada gembala-gembala/pelayan-pelayan yang berarti pengatur rumah yang dipercayakan rahasia Allah; melayani dengan sukacita, tanpa pujian dan sanjungan orang lain.

\section{Pertumbuhan Dalam Pelayanan}

Prioritas pelayanan di GBI Sungai Yordan adalah visitasi / perkunjungan jemaat. Perhatian 'pribadi' bagi anggota jemaat merupakan pokok dari pelayanan pastoral. Bagi gereja yang dipercayakan Tuhan kepada Penulis, maka pelayanan :

Pertama, Perkunjungan adalah pusat panggilan orang percaya. Kedua, Manusia membutuhkan "kontak" penggembalaan. Pendeta tidak hanya memperhatikan hal-hal rohani, tetapi perkara yang lain. Ketiga, Penggembalaan merupakan cara utama untuk menjelmakan kasih. Injil Yohanes 1:14 mengatakan bahwa Firman itu telah menjadi manusia dan "diam" di antara kita. Gembala Sidang / Wakilnya yang datang mengunjungi jemaat merupakan "bukti" mengasihi jemaat.
Di samping itu juga terdapat kesalahpahaman tentang perkunjungan.

a. Perkunjungan adalah penggunaan waktu yang tidak effisien.

= waktu berkunjung dapat mengetahui keadaan jemaat.

a. Perkunjungan terlalu sulit dijadwalkan. Masyarakat kota terlalu sibuk, di rumah pasti tidak berada di tempat. Bagaimana caranya?

= telepon untuk janji bertemu dan datang ke kantor/pekerjaan dalam waktu yang singkat.

b. Perkunjungan menanggung resiko dan menakutkan. Melayani satu orang lebih sulit dibanding dengan banyak orang. Justru sebaliknya, melayani satu orang lebih mudah! Waktu perkunjungan itu dapat membangun pelayanan yang lebih baik. Khotbah diperkaya : mempelajari jemaat dan mempelajari Alkitab. Administrasi diperlancar : program pelayanan gereja dapat direncanakan lebih tepat untuk mengenai sasaran. Berbagai krisis dapat dihindari : krisis depresi/stress dihindari (yang

bersangkutan). Orang yang bermasalah didatangi dan mereka lebih tenang, karena dapat menceritakan persoalannya. Pelayanan diperkokoh : mendengarkan komentar pelayanan gembala dari jemaat.

Pelayanan yang lain adalah dengan mengunjungi orang di tempat pekerjaan. Hal ini merupakan :

1. Menunjukkan perhatian Gembala Sidang

2. Pekerjaan sehari-hari jemaat dihargai

3. Adanya kesempatan-kesempatan mengembangkan pelayanan yang lebih baik

4. Pengajaran Kristus dapat dihubungkan dengan pekerjaan

5. Pelayanan dapat dilakukan untuk masyarakat ... menjadi kesaksian yang

baik untuk orang lain

\section{Pemberdayaan Kaum Awam}

Apakah "Pelayanan" itu ? Semua jemaat di GBI Sungai Yordan Surabaya dibekali dengan tehnik-tehnik pelayanan.

1. Pemberi Kesaksian : "Ada tempat di mana Allah bekerja dan di sana

Tuanku (Naaman) disembuhkan dari penyakit kusta" (II Raja-raja 5:3,10)

2. Memuridkan : "Elia memuridkan Elisa: "Ikutlah aku .... ." (I Raja-raja 19:19-21)

3. Menyediakan tempat untuk pelayanan (rumah) : Maria, Marta dan Lazarus

dalam Yohanes 12:1-3 
4. Membuka rumah untuk persekutuan / pelayanan: Lidia $\square$ rumahnya

menjadi tempat strategis sebagai gereja pertama di Eropa (Kisah Para Rasul

$16: 14-15)$

5. Mendidik orang lain menjadi pengkhotbah yang berbakat (Kisah Para Rasul 18:24-26). Seperti Priskila dan Akwila yang mendidik Apolos.

Di samping itu juga ada beberapa hambatan untuk pelayanan Kaum Awam, seperti :

1. Perasaan kurang layak, karena tidak memiliki pengetahuan dan

keterampilan.

2. Menolak kewajiban. Jika berkata: "Aku tidak layak", siapa yang layak??? Tuhan berkata: "Lakukanlah!"

3. Takut gagal : Berdoa, tetapi tidak terjadi apa-apa: Ketika tidak melihat

hasil doa, sebenarnya Allah tetap bekerja !Cara : menekankan bahwa pelayanan itu tidak berarti mendapat jawaban!

Di GBI Sungai Yordan Surabaya telah memberikan beberapa model pelayanan seperti berikut ini :

1. Pelayanan Materi : uang/barang untuk menolong jemaat yang membutuhkan.

2. Pelayanan Rohani : memperkenalkan orang kepada Yesus Kristus dan kepada

kehidupan dalam Roh Kudus,- dipimpin oleh Roh

(Roma 8 ); hidup lahir baru

menjadi ciptaan baru (bukan Kristen KTP / tanpa pertobatan)

3. Pelayanan Kesembuhan : membuat orang lain sehat, baik fisik, mental dan emosional.

4. Pelayanan Kenabian : mengubah cara hidup manusia di dalam struktur

masyarakat. Meningkatkan cara hidup masyarakat (terutama di daerah pedalaman)

\section{Kepustakaan}

[1] Alkitab, Lembaga Alkitab Indonesia, 1992.

[2] Abineno, J.L. Ch. Pedoman Praktis untuk Pelayanan Pastoral. Jakarta: BPK

Gunung Mulia, 1991).

[3] Abineno, J.L. Ch. Diaken. Jakarta : BPK Gunung Mulia, 1994.

[4] Atiyanto, Sridadi. Sekelumit tentang Diakon. Bandung : Lembaga Literatur Baptis, 1984.

[5] Anthony, L., Diktat Kuliah Pelayanan Pastoral. Yogyakarta : STTII, T.Th.

[6] Brink, Ds. H.v.d., Tafsiran Alkitab Kisah Para Rasul. Jakarta : BPK Gunung Mulia, 2003.

[7] B.S., Jusuf, et. al., Sebuah Bunga Rampai Pertumbuhan Gereja. Yogyakarta : Andi Offset, 1994.
[8] Ciptawilangga, Yunus dan Matius N. Heryanto, Menang dalam Persaingan Gereja. Jakarta : Metanoia, 2003.

[9] C. Ortlund, Raymound. Filsafat Pelayanan Berdasarkan Alkitab. Surabaya : Yakin, T.Th.

[10] Faot, Agustinus, Jonathan Octavianus, and D. R. Juanda. "Kematian Bukan Akhir Dari Segalanya." Journal Kerusso 2.2 (2017): 15-30.

[11] Juanda, D. R. "Melayani Kristus Dengan Karya Tulis." Journal Kerusso 2.1 (2017): 4554.

[12] Larson, Bruce, dkk. Pelayanan Penggembalaan yang Ideal. Malang : Gandum Mas, 1996.

[13] Lontoh, Frederich Oscar. "Pengaruh Gaya Kepemimpinan, Ketrampilan Komunikasi Dan Kotbah Terhadap Komitmen Organisasional Jemaat Di GKI Dasa Surabaya." Journal Kerusso 2.1 (2017): 1-17.

[14] Permana, S., Lontoh, F. O. L., Kusuma, S., Verhezen, P., \& Lily, T. (2018). CORRELATION STUDY OF CHURCH LEADERSHIP TOWARDS CHURCH MEMBER COMMITMENT IN CHRISTIAN CHURCH OF INDONESIA DARMO SATELIT SURABAYA-JAWA TIMUR. Sinergi: Jurnal Ilmiah Ilmu Manajemen, 8(2).

[15] Riemer, G. Cermin Injil. Jakarta : Yayasan Komunikasi Bina Kasih, 1995.

[16] Tidball, Derek J. Teologi Penggembalaan. Malang : Gandum Mas, 1995.

[17] Vine,W.E., et. al., Vine's Complete Expository Dictionary of Biblical Words. New York : Thomas Nelson Publisher, 1985. 